\title{
Article \\ Sustainable and Resistant Road Infrastructures: The Role of the Envision Framework as a Guide to a New Design Approach
}

\author{
Francesco Censorii ${ }^{1}$, Luca Cotignoli ${ }^{1}$, Valeria Vignali ${ }^{1, *}$ (i) and Alberto Bartoli ${ }^{2}$ \\ 1 Department of Civil, Chemical, Environmental and Materials Engineering, School of Engineering, \\ University of Bologna, 40126 Bologna, Italy; francesco.censorii@studio.unibo.it (F.C.); \\ luca.cotignoli2@studio.unibo.it (L.C.) \\ 2 Ingegneri Riuniti S.p.A., 41126 Modena, Italy; a.bartoli@ingegneririuniti.it \\ * Correspondence: valeria.vignali@unibo.it
}

Citation: Censorii, F.; Cotignoli, L.; Vignali, V.; Bartoli, A. Sustainable and Resistant Road Infrastructures: The Role of the Envision Framework as a Guide to a New Design Approach. Coatings 2022, 12, 236. https://doi.org/10.3390/coatings 12020236

Academic Editor: Qiao Dong

Received: 20 December 2021

Accepted: 8 February 2022

Published: 11 February 2022

Publisher's Note: MDPI stays neutral with regard to jurisdictional claims in published maps and institutional affiliations.

Copyright: (C) 2022 by the authors. Licensee MDPI, Basel, Switzerland. This article is an open access article distributed under the terms and conditions of the Creative Commons Attribution (CC BY) license (https:// creativecommons.org/licenses/by/ $4.0 /)$.

\begin{abstract}
In Italy, resilience and sustainability concepts are generally applied to road infrastructures (mainly in terms of pavements) in order to minimize the environmental impacts of their construction and maintenance. In this paper the Envision framework has been adopted to evaluate the sustainability of a road project, optimizing its resilience for both short-term and long-term impacts. The rating approach has been applied considering not only pavements analysis but also the complete project process. The authors have upgraded the original Envision framework to road infrastructures, in compliance with the Italian regulatory framework. Four scenarios have been considered. The first allowed us to understand which credits can be evaluated with the available project documentation. The second represents a snapshot of the state of the project. The third evaluates the effect of the improvement in the performance level obtained by analyzing the potential increases. Finally, the last considers also for "pending" credits.
\end{abstract}

Keywords: sustainability; Envision framework; credits; guidelines; road; design

\section{Introduction}

Sustainability indicates a development that meets the needs of the present without compromising the capacity to satisfy the needs of future generations.

The 2030 Sustainable Development Agenda is a program for people, for the planet, and for prosperity, which comprises 17 objectives for sustainable development in a big action program made of 169 targets. The ninth point of the list is the willingness to construct resilient infrastructures and promote innovation and equal, responsible, and sustainable industrialization [1].

Nowadays, there is considerable evidence that road infrastructures have a significant impact on the environment. Their sustainability and resilience are critical factors for a sustainable development path. Thus, road transportation systems need to be planned, designed, constructed, and maintained in order to properly manage the potentially negative environmental and social impacts and risks. Important benefits can be associated with a sustainable road project, including improved cost effectiveness, reduced material consumption, increased protection of finite environmental resources, and improved consideration of a life-cycle approach [2-11].

In Italy, resilience and sustainability concepts have generally been applied to road infrastructures mainly in terms of pavements in order to minimize the environmental impacts of their construction and maintenance. The aims here are related to using eco-friendly construction techniques, to reduce the use of virgin raw materials, and to promote the recycling and reuse of the so-called secondary raw materials (materials which, after complete initial use, may be used repeatedly in production as starting material) [12,13]. Many innovative and environmentally friendly materials have been launched, and others are still under study including rubber [14-20], bleaching clays from the food industry [21,22], glass 
powder [23], construction and demolition waste aggregates [24], fly ash aggregates [25,26], and plastic waste [27-30].

Many systems for the sustainability evaluation of road infrastructure have been developed worldwide. They can be mainly grouped in three categories: the first one includes the conventional project appraisal methods for decision-making such as cost-benefits analysis (CBA) or multi-criteria decision analysis (MCDA) among others. The second one comprises techniques for assessing environmental and social impact of infrastructure projects including life-cycle assessment (LCA) and social life-cycle assessment (SLCA). Rating systems, frameworks, and guidelines belong to the last category and are used to score infrastructure projects through sustainability assessment.

Moreover, indices and composite indicators are powerful tools which can be used for the assessment of technical, environmental, and economic performance of future or existing roads [31]. Singh et al. investigated the advantages of indices, which are the multidimensionality and the robust formulation based on scientific rules and statistical models [32]. Indices and indicators have to be selected and reviewed in accordance with the boundary condition of the case study to develop a consistent framework.

Focusing on the different type of methodologies, the improvement of assessment tools towards a complete view of all the aspects of sustainability requires great effort. The traditional decision-making systems are powerful tools for assessing transport project, but they present weakness in addressing sustainability issues comprehensively. For example, life-cycle analysis is strongly affected by the variables and the available data characteristic of the case study, which influence the results. Moreover, this analysis is only concerned with the operative phases, overlooking many other important factors [33]. On the other hand, rating systems provide guidelines to incorporate the best sustainability practices in the different steps of the project life-cycle from planning right through to construction and maintenance. Rating systems, due to their highly flexible and resilient structure, have been largely applied and accepted by practitioners in the civil engineering fields. The developed framework in support of a rating system provides consistent advice for transport projects with particular reference to environmental issues. These solutions are suited for construction process and materials rather than operational phases, establishing significant criteria for assessing options [34].

The most notable characteristics of rating systems are the comprehensive approach and the quantitative process developed to deal with sustainability issues. Evaluation systems have been elaborated by trusted private and governmental authorities working with researchers in academia. In United States, many rating systems have been established to enhance the sustainability of construction projects. GreenLITES (Green Leadership in Transportation and Environmental Sustainability), developed by the New York State Department of Transportation, presents two certification programs. The first one is dedicated to project designs and the second is intended for operations. Each construction program is appraised with an appropriate certification level. Greenroads is a collection of the best practices, based on the evaluation of project requirements and voluntary core and extra credit points, commonly used for roadway constructions [35]. The Envision framework is the most recent rating system used for project and construction of a sustainable infrastructure. It has been developed by the Institute for Sustainable Infrastructure (ISI) in collaboration with the Zofnass Program for Sustainable Infrastructure of the Harvard University Graduate School of design and it defines the sustainability rating of an infrastructure [36]. The criterion was established mainly for the design and project development process, but the recent version has expanded its application also to the process of construction, operation, maintenance, and demolition. In addition to the certification, the objective of Envision is to promote sustainable solution in technical, environmental, social and economic terms, providing goals and performance levels through the guidelines. This rating system consists of five sections: quality of life, leadership, resource allocation, natural world, and climate and risk, each of which is further divided in sub-categories (Figure 1). 


\begin{tabular}{|c|c|c|c|c|}
\hline $\begin{array}{l}\text { Quality } \\
\text { Of Life } \\
14 \text { Credits }\end{array}$ & $\begin{array}{l}\text { Leadership } \\
12 \text { Credits }\end{array}$ & $\begin{array}{l}\text { Resource } \\
\text { Allocation } \\
14 \text { Credits }\end{array}$ & $\begin{array}{l}\text { Natural } \\
\text { World } \\
14 \text { Credits }\end{array}$ & (12) $\begin{array}{l}\text { Climate and } \\
\text { Resilience } \\
10 \text { Credits }\end{array}$ \\
\hline WELLBEING & COLLABORATION & MATERIALS & SITING & EMISSIONS \\
\hline Q11.1 Improve Community Quality of life L & LD1.1 Provide Effective Leadership\& Commitment & RA1.1 Support Sustainable Procurement Practices & NW1.1 Preserve Sites of High Ecological Valuve & CR1.1 Reduce Net Embodied Carbon \\
\hline Q11.2 Enhance Public Health \& Safely & LD1.2 Foster Collaboration \& Teamwork & RA1.2 Use Recycled Materials & NW1.2 Provide Wetland \& Surface Water Buffers & CR1.2 Reduce Greenhouse Gas Emissions \\
\hline Q11.3 Improve Construction Safety & LD1.3 Provide for Stakeholder Involvement & RA1.3 Reduce Operational Waste & NW1.3 Preserve Prime Farmland & CR1.3 Reduce Air Pollutant Emissions \\
\hline Q11.4 Minimize Noise \&Vibration & LD1.4 Pursue Byproduct Synergies & RA1.4 Reduce Construction Waste & NW1.4 Preserve Undeveloped Land & \\
\hline QL1.5 Minimize light Pollution & & RA1.5 Balance Earthwork On Site & & RESILIENCE \\
\hline Q11.6 Minimize Construction Impacts & PLANNING & & $\begin{array}{l}\text { CONSERVATION } \\
\text { NW2.1 Reclaim Brownfields }\end{array}$ & CR2.1 Avoid Unsuitable Development \\
\hline & LD2.1 Establish a Sustainability Management Plan & ENERGY & $\begin{array}{l}\text { NW2.1 Reddim Brownfields } \\
\text { NW2.2 Manage Stormwater }\end{array}$ & CR2.2 Assess Climate Change Vulnerability \\
\hline MOBILITY & LD2.2 Plan for Sustainable Communities & RA2.1 Reduce Operational Energy Consumption & & CR2.3 Evaluate Risk \& Resilience \\
\hline $\begin{array}{l}\text { Q12.1 Improve Community Mobility \& Access } \\
\text { Q12.2 Encourge Sustainable Transportation }\end{array}$ & LD2.3 Plan for Long-Term Monitoring \& Maintenance & RA2.2 Reduce Construction Energy Consumption & 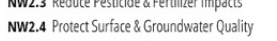 & CR2.4 Establish Resilience Goals and Strategies \\
\hline Q12.3 Improve Access \& Wayfinding & LD2.4 Plan for End-of-life & RA2.4 Commission \& Monitor Energy Systems & & CR2.5 Maximize Resilience \\
\hline & ECONOMY & & ECOLOGY & CR2.6 Improve Infrastructure Integration \\
\hline COMMUNITY & LD3.1 Stimulate Economic Prosperity \& Development & WATER & & CRO0. IInovate or Exceed Credit Requirements \\
\hline Q13.1 Advance Equity \& Social Justice & LD3.2 Develop Local Skills \& Capabilities & RA3.1 Preserve Water Resources & $\begin{array}{l}\text { NW3.2 Enhance Wettand \& Surface Water Functions } \\
\text { NW3.3 Maintain Floodplain Functions }\end{array}$ & \\
\hline Q13.2 Preserve Historic\& Cultural Resources & L03.3 Conducta L life-Cycle Economic Evaluation & RA3.2 Reduce Operational Water Consumption & & \\
\hline $\begin{array}{l}\text { Q13.3 Enhance Views \& Local Character } \\
\text { Q13.4 Enhance Public Space \&Amenities }\end{array}$ & LD0.0 Innovate or Exceed Credit Requirements & $\begin{array}{l}\text { RA3.3 Reduce Construction Water Consumption } \\
\text { RA3.4 Monitor Water Systems }\end{array}$ & NW3.5 Protect Soil Health & \\
\hline QL0.0 Innovate or Exceed Credit Requirements & & RA0.0 Innovate or Exceed Credit Requirements & NW0.0 Inovate or Exceed Credit Requirements & \\
\hline
\end{tabular}

Figure 1. Categories and credits.

Each category is characterized by a basket of credits that can be satisfied by presenting adequate documentation necessary for the definition of the level of performance of the infrastructure.

Envision's performance levels of achievement define the level and quality of project performance in each credit as follows:

- Improved performance superior to conventional;

- Enhanced sustainability performance is on track;

- Superior sustainable performances at a very high level but which still have a residual impact;

- Conserving performance that has achieved almost zero impact;

- Restorative benefits that restore natural and/or social systems.

The evaluation criteria and the documentation section within each credit outline are necessary to demonstrate that a level of performance has been achieved. The evaluation criteria, indicated with letters, include both qualitative and quantitative requirements. All evaluation criteria are defined as questions, for which it is necessary to provide answers and supporting documentation if the project is sent for an evaluation verification to a third-party certification body, the ISI.

The application of a rating system depends on the analysis characteristics and many critical reviews were carried out to compare the potential of these tools for assisting practitioners in reaching environmentally sustainable goals. Mattinzioli et al. have investigated the most prominent current rating systems and determined that Envision evaluates the three-pillars of sustainability, macro-categories and life-cycle more homogenously than other systems [37]. Moreover, Envision turned out to be the most suitable green rating systems for Hungarian infrastructure design as a result of the application of a multi-objective decision-making method for the comparison of traditional rating systems [38].

Among the aforementioned rating systems and in accordance with the previous considerations, in this paper the Envision framework has been implemented to upgrade the project of an existing road infrastructure in the north of Italy. The innovative aspect of this project research is the application of Envision framework to a real Italian road, considering not only pavements materials analysis but also the complete project process. The authors have upgraded the original Envision framework to road infrastructures, in compliance with the Italian regulatory framework.

The paper proceeds as follows: Section 2 explains the upgraded guideline defined for a road infrastructure, Section 3 illustrates its application to a real case study, and Section 4 shows the obtained results. 


\section{The Guidelines for a Road Infrastructure}

The authors have upgraded the original Envision framework to road infrastructures, in compliance with the Italian regulatory framework.

A document which is easy to be interpreted, which clearly defines the requests for each credit, and the documents to be presented to support them, have been developed.

For each credit the title of the claim (which provided a focus of the scope), its intent, the measurement method to be adopted, the maximum assignable score, the level of performance distinguishing the evaluation principles and the paths to be followed to reach them, the description of the credit provided by the framework, the explanation of each performance level (from 'improved' to 'restorative'), the evaluation criteria, the documentation to be presented, and the related credits have been evaluated.

A credit description was developed based on the personal interpretation of the application context and the description provided.

The list of requests for the credit evaluation was defined on the basis of those reported in the framework. The requests contained letters ranging from A to $G$ and could be cumulative for the satisfaction of the highest credit levels.

The documentation necessary to respond to requests has been outlined in compliance with Italian legislation. The required documentation may consist of general and specialist reports technical drawings, calculations of areas, and weights or volumes. However, anything deemed pertinent to the credit satisfaction can be presented, including photos, notes, and documents developed in course of work that allow one to achieve a certain score for a specific credit.

\section{The Project Object of Study}

The project object of study is the upgrade of a road infrastructure in Italy.

It is a dual carriageway road, with two lanes plus the emergency lane in each direction (Figure 2), and it is frequently characterized by traffic congestion and very low levels of service.

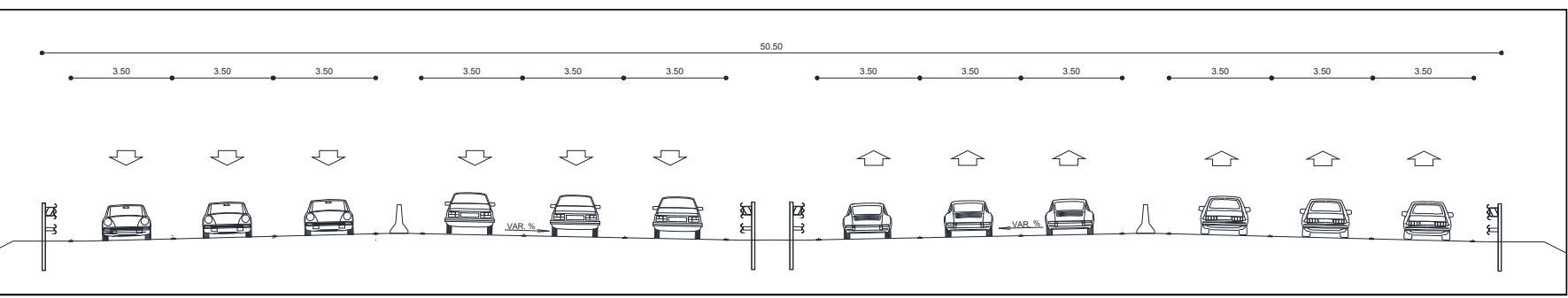

Figure 2. Cross section of the carriageway of the road object of study.

For these reasons the upgrade project has been developed in order to improve its circulation level and the road safety.

The project involves an internal carriageway with three lanes plus emergency per direction and of an external one with four lanes plus emergency per direction (Figure 3).

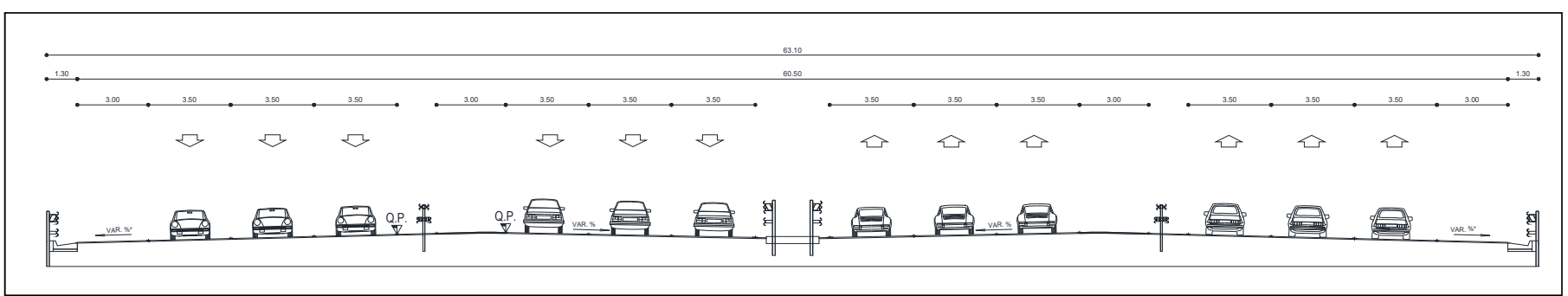

Figure 3. Cross section of the designed carriageway of the road object of study. 
The road hub was redesigned as an opportunity for development for the city and the areas directly involved in the work [39]. As a result, the project has paid attention to both environmental and transport topics consisting of:

- The redevelopment of green areas for environmental integration;

- The creation of wooded strips, flyovers, and noise barriers of architectural value;

- The valorization of cycle and pedestrian paths;

- The creation of important transport works and the improvement of the junctions with local roads.

The institutional bodies involved, moreover, decided to have a public discussion open to all townspeople before the definitive design with the aim of explaining the project, answering questions, and collecting comments and suggestions.

\section{Methods}

The application of the Envision framework to the project required a deep study due to the amount of available technical documentation. It started from the knowledge of the work, going back through its history, to what it is today.

The final project was evaluated in order to determine the possible interventions and improvements to be made in the executive project phase in order to obtain a higher Envision rating.

A rating was defined in relation to the current status of the project, and subsequently it was decided to face a credit for each category, defining the actions to be taken to move to the next level of performance.

Since the documents relating to the construction and operation phase will be available only at the end of the construction of the work, project assessment scenarios have been hypothesized.

Four scenarios have been considered: two limited to the actual state of the design, and two defined assuming a series of actions to be undertaken. Both allow the designers and the owner of the work to understand the current level and the future increase of the rating.

So, the evaluation process was divided into two different phases, each containing two scenarios.

Firstly, for all the credits envisaged by the framework, a colored scale has been defined, in order to obtain a simple tool to analyze and explain the score for each performance level achieved by one credit. According to this scale:

- Yellow: the credit is consistent with the project and so it is considered in the total score;

- Green: the credit is consistent with the project phase object of study and so it is considered in the total score;

- Red: the credit assumes a valuation equal to zero since there is not documentation about it;

- Blue: the credit is inconsistent with the project and so it is not considered in the total score.

Then, in the first phase, two evaluation scenarios limited to the actual state of the design have been considered, assuming that:

- The credits that can be assessed are only those in the planning phase;

- The available documentation satisfies the credit;

- Credits inconsistent with the type of work are not considered in the total score;

- Credits without documentation assume a valuation equal to zero.

The first scenario (Scenario 1), in particular, analyses which credits of the framework the available project documentation can answer. Figure 4 shows the maximum value that each credit can assume. In this way, it is possible to understand the project position in the framework evaluation scale and provide feedback on the missing documents. 


\begin{tabular}{|c|c|c|c|c|c|}
\hline CREDIT & IMPROVED & ENHANCED & SUPERIOR & CONSERVING & RESTORATIVE \\
\hline \multicolumn{6}{|l|}{ QUALITY OF LFE } \\
\hline \multicolumn{6}{|l|}{ WELLBEING } \\
\hline QL1.1 Improve Community Quality of Life & 2 & 5 & 10 & 20 & 26 \\
\hline QL1.2 Enhance Public Health \& Safety & 2 & 7 & 12 & 16 & 20 \\
\hline QL1.3 Improve Construction Safety & 2 & 5 & 10 & 14 & - \\
\hline QL1.4 Minimize Noise \& Vibration & 1 & 3 & 6 & 10 & 12 \\
\hline QL1.5 Minimize Light Pollution & 1 & 3 & 6 & 10 & 12 \\
\hline QL1.6 Minimize Construction Impacts & 1 & 2 & 4 & 8 & - \\
\hline \multicolumn{6}{|l|}{ MOBILTY } \\
\hline QL2.1 Improve Community Mobility \& Access & 1 & 3 & 7 & 11 & 14 \\
\hline QL2.2 Encourage Sustainable Transportation & - & 5 & 8 & 12 & 16 \\
\hline QL2.3 Improve Access \& Wayfinding & 1 & 5 & 9 & 14 & - \\
\hline \multicolumn{6}{|l|}{ COMMUNITY } \\
\hline Q.3.1 Advance Equity \& Social Justice & 3 & 6 & 10 & 14 & 18 \\
\hline QL3.2 Preserve Historic \& Cultural Resources & - & 2 & 7 & 12 & 18 \\
\hline QL3.3 Enhance Views \& Local Character & 1 & 3 & 7 & 11 & 14 \\
\hline Q.2.4.4 Enhance Public Space \& Amenities & 1 & 3 & 7 & 11 & 14 \\
\hline \multicolumn{6}{|l|}{ LEADERSHIP } \\
\hline \multicolumn{6}{|l|}{ COLLABORATION } \\
\hline LD1.1 Provide Effective Leadership \& Commitment & 2 & 5 & 12 & 18 & - \\
\hline LD1.2 Foster Collaboration \& Teamwork & 2 & 5 & 12 & 18 & - \\
\hline LD1.3 Provide for Stakeholder Involvement & 3 & 6 & 9 & 14 & 18 \\
\hline LD1.4 Pursue Byproduct Synergies & 3 & 6 & 12 & 14 & 18 \\
\hline \multicolumn{6}{|l|}{ PLANNING } \\
\hline LD2.1 Establish a Sustainability Management Plan & 4 & 7 & 12 & 18 & - \\
\hline LD2.2 Plan for Sustainable Communities & 4 & 6 & 9 & 12 & 16 \\
\hline LD2.3 Plan for Long-Term Monitoring \& Maintenance & 2 & 5 & 8 & 12 & - \\
\hline LD2.4 Plan for End-of-Life & 2 & 5 & 8 & 14 & - \\
\hline \multicolumn{6}{|l|}{ ECONOMY } \\
\hline LD3.1 Stimulate Economic Prosperity \& Development & 3 & 6 & 12 & 20 & - \\
\hline LD3.2 Develop Local Skills \& Capabilities & 2 & 4 & 8 & 12 & 16 \\
\hline LD3.3 Conduct a Life-Cycle Economic Evaluation & 5 & 7 & 10 & 12 & 14 \\
\hline
\end{tabular}

LD3.3 Conduct a Life-Cycle Economic Evaluation

\begin{tabular}{|c|c|c|c|c|c|}
\hline \multirow{2}{*}{\multicolumn{6}{|c|}{\begin{tabular}{|l|} 
NATURAL WORLD \\
SITING \\
\end{tabular}}} \\
\hline & & & & & \\
\hline \begin{tabular}{|l} 
NW1.1 Preserve Sites of High Ecological Value \\
\end{tabular} & 2 & 6 & 12 & 16 & 22 \\
\hline NW1.2 Provide Wetland \& Surface Water Buffers & 2 & 5 & 10 & 16 & 20 \\
\hline NW1.3 Preserve Prime Farmland & - & 2 & 8 & 12 & 16 \\
\hline NW1.4 Preserve Undeveloped Land & 3 & 8 & 12 & 18 & 24 \\
\hline \multicolumn{6}{|l|}{ CONSERVATION } \\
\hline NW2.1 Reclaim Brownfields & 11 & 13 & 16 & 19 & 22 \\
\hline NW2.2 Manage Stormwater & 2 & 4 & 9 & 17 & 24 \\
\hline NW2.3 Reduce Pesticide \& Fertilizer Impacts & 1 & 2 & 5 & 9 & 12 \\
\hline NW2.4 Protect Surface \& Groundwater Quality & 2 & 5 & 9 & 14 & 20 \\
\hline \multicolumn{6}{|l|}{ ECOLOGY } \\
\hline \begin{tabular}{|l} 
NW3.1 Enhance Functional Habitats \\
\end{tabular} & 2 & 5 & 9 & 15 & 18 \\
\hline NW3.2 Enhance Wetland \& Surface Water Functions & 3 & 7 & 12 & 18 & 20 \\
\hline NW3.3 Maintain Floodplain Functions & 1 & 3 & 7 & 11 & 14 \\
\hline NW3.4 Control Invasive Species & 1 & 2 & 6 & 9 & 12 \\
\hline NW3.5 Protect Soil Health & - & 3 & 4 & 6 & 8 \\
\hline \multicolumn{6}{|l|}{ CLIMATE AND RESILIENCE } \\
\hline \multicolumn{6}{|l|}{ EMISSIONS } \\
\hline \begin{tabular}{|l|} 
CR1.1 Reduce Net Embodied Carbon \\
\end{tabular} & 5 & 10 & 15 & 20 & - \\
\hline CR1.2 Reduce Greenhouse Gas Emissions & 8 & 13 & 18 & 22 & 26 \\
\hline CR1.3 Reduce Air Pollutant Emissions & 2 & 4 & 9 & 14 & 18 \\
\hline \multicolumn{6}{|l|}{ RESILIENCE } \\
\hline \begin{tabular}{|l} 
CR2.1 Avoid Unsuitable Development \\
\end{tabular} & 3 & 6 & 8 & 12 & 16 \\
\hline CR2.2 Assess Climate Change Vulnerability & 8 & 14 & 18 & 20 & - \\
\hline CR2.3 Evaluate Risk \& Resilience & 11 & 18 & 24 & 26 & - \\
\hline CR2.4 Establish Resilience Goals and Strategies & - & 8 & 14 & 20 & - \\
\hline CR2.5 Maximize Resilience & 11 & 15 & 20 & 26 & - \\
\hline CR2.6 Improve Infrastructure Integration & 2 & 5 & 9 & 13 & 18 \\
\hline
\end{tabular}

\begin{tabular}{|l|l|}
\hline & Credit applicable \\
\hline & Credit not applicable at this phase \\
\hline & Zero rating \\
\hline & Credit not applicable \\
\hline
\end{tabular}

Figure 4. Scenario 1: analysis of the credits to which the available project documentation can answer.

The second evaluation scenario (Scenario 2), instead, has been defined assuming that the consulted documentation allowed the real value of the credit to be defined (Figure 5). In this way is possible to associate the right value of the project documentation to the credits selected in Scenario 1. In this way the Envision evaluation of the project's status is obtained. 


\begin{tabular}{|c|c|c|c|c|c|}
\hline CREDIT & IMPROVED & ENHANCED & SUPERIOR & CONSERVING & RESTORATIVE \\
\hline \multicolumn{6}{|l|}{ QUALITY OF LIFE } \\
\hline \multicolumn{6}{|l|}{ WELLBEING } \\
\hline QL1.1 Improve Community Quality of Life & 2 & 5 & 10 & 20 & 26 \\
\hline QL1.2 Enhance Public Health \& Safety & 2 & 7 & 12 & 16 & 20 \\
\hline QL1.3 Improve Construction Safety & 2 & 5 & 10 & 14 & - \\
\hline QL1.4 Minimize Noise \& Vibration & 1 & 3 & 6 & 10 & 12 \\
\hline QL1.5 Minimize Light Pollution & 1 & 3 & 6 & 10 & 12 \\
\hline QL1.6 Minimize Construction Impacts & 1 & 2 & 4 & 8 & - \\
\hline \multicolumn{6}{|l|}{ MOBILTY } \\
\hline QL2.1 Improve Community Mobility \& Access & 1 & 3 & 7 & 11 & 14 \\
\hline QL2.2 Encourage Sustainable Transportation & - & 5 & 8 & 12 & 16 \\
\hline Q.2.2.3 Improve Access \& Wayfinding & 1 & 5 & 9 & 14 & - \\
\hline \multicolumn{6}{|l|}{ COMMUNITY } \\
\hline QL3.1 Advance Equity \& Social Justice & 3 & 6 & 10 & 14 & 18 \\
\hline QL3.2 Preserve Historic \& Cultural Resources & - & 2 & 7 & 12 & 18 \\
\hline QL3.3 Enhance Views \& Local Character & 1 & 3 & 7 & 11 & 14 \\
\hline QL3.4 Enhance Public Space \& Amenities & 1 & 3 & 7 & 11 & 14 \\
\hline \multicolumn{6}{|l|}{ LEADERSHIP } \\
\hline \multicolumn{6}{|l|}{ COLLABORATION } \\
\hline LD1.1 Provide Effective Leadership \& Commitment & 2 & 5 & 12 & 18 & - \\
\hline LD1.2 Foster Collaboration \& Teamwork & 2 & 5 & 12 & 18 & - \\
\hline LD1.3 Provide for Stakeholder Involvement & 3 & 6 & 9 & 14 & 18 \\
\hline LD1.4 Pursue Byproduct Synergies & 3 & 6 & 12 & 14 & 18 \\
\hline \multicolumn{6}{|l|}{ PLANNING } \\
\hline LD2.1 Establish a Sustainability Management Plan & 4 & 7 & 12 & 18 & - \\
\hline LD2.2 Plan for Sustainable Communities & 4 & 6 & 9 & 12 & 16 \\
\hline LD2.3 Plan for Long-Term Monitoring \& Maintenance & 2 & 5 & 8 & 12 & - \\
\hline LD2.4 Plan for End-of-Life & 2 & 5 & 8 & 14 & - \\
\hline \multicolumn{6}{|l|}{ ECONOMY } \\
\hline LD3.1 Stimulate Economic Prosperity \& Development & 3 & 6 & 12 & 20 & - \\
\hline LD3.2 Develop Local Skills \& Capabilities & 2 & 4 & 8 & 12 & 16 \\
\hline LD3.3 Conduct a Life-Cycle Economic Evaluation & 5 & 7 & 10 & 12 & 14 \\
\hline
\end{tabular}

\begin{tabular}{|c|c|c|c|c|c|}
\hline \multicolumn{6}{|l|}{ RESOURCE ALLOCATION } \\
\hline \multicolumn{6}{|l|}{ MATERIALS } \\
\hline RA1.1 Support Sustainable Procurement Practices & 3 & 6 & 9 & 12 & - \\
\hline RA1.2 Use Recycled Materials & 4 & 6 & 9 & 16 & $\begin{array}{l}- \\
\end{array}$ \\
\hline RA1.3 Reduce Operational Waste & 4 & 7 & 10 & 14 & - \\
\hline RA1.4 Reduce Construction Waste & 4 & 7 & 10 & 16 & - \\
\hline RA1.5 Balance Earthwork On Site & 2 & 4 & 6 & 8 & - \\
\hline \multicolumn{6}{|l|}{ ENERGY } \\
\hline RA2.1 Reduce Operational Energy Consumption & 6 & 12 & 18 & 26 & - \\
\hline RA2.2 Reduce Construction Energy Consumption & 1 & 4 & 8 & 12 & - \\
\hline RA2.3 Use Renewable Energy & 5 & 10 & 15 & 20 & 24 \\
\hline RA2.4 Commission \& Monitor Energy Systems & 3 & 6 & 12 & 14 & - \\
\hline \multicolumn{6}{|l|}{ WATER } \\
\hline RA3.1 Preserve Water Resources & 3 & 5 & 7 & 9 & 12 \\
\hline RA3.2 Reduce Operational Water Consumption & 4 & 9 & 13 & 17 & 22 \\
\hline RA3.3 Reduce Construction Water Consumption & 1 & 3 & 5 & 8 & - \\
\hline RA3.4 Monitor Water Systems & 1 & 3 & 6 & 12 & - \\
\hline
\end{tabular}

\begin{tabular}{|c|c|c|c|c|c|}
\hline \multicolumn{6}{|l|}{\begin{tabular}{|l|} 
NATURAL WORLD \\
STING
\end{tabular}} \\
\hline \multicolumn{6}{|l|}{ SITING } \\
\hline \multirow{2}{*}{$\begin{array}{l}\text { NW1.1 Preserve Sites of High Ecological Value } \\
\text { NW1.2 Provide Wetland \& Surface Water Buffers }\end{array}$} & 2 & 6 & 12 & 16 & 22 \\
\hline & 2 & 5 & 10 & 16 & 20 \\
\hline $\begin{array}{l}\text { NW1.3 Preserve Prime Farmland } \\
\text { Noll }\end{array}$ & - & 2 & 8 & 12 & 16 \\
\hline NW1.4 Preserve Undeveloped Land & 3 & 8 & 12 & 18 & 24 \\
\hline \multicolumn{6}{|l|}{ CONSERVATION } \\
\hline NW2.1 Reclaim Brownfields & 11 & 13 & 16 & 19 & 22 \\
\hline NW2.2 Manage Stormwater & 2 & 4 & 9 & 17 & 24 \\
\hline NW2.3 Reduce Pesticide \& Fertilizer Impacts & 1 & 2 & 5 & 9 & 12 \\
\hline NW2.4 Protect Surface \& Groundwater Quality & 2 & 5 & 9 & 14 & 20 \\
\hline \multicolumn{6}{|l|}{ ECOLOGY } \\
\hline NW3.1 Enhance Functional Habitats & 2 & 5 & 9 & 15 & 18 \\
\hline NW3.2 Enhance Wetland \& Surface Water Functions & 3 & 7 & 12 & 18 & 20 \\
\hline NW3.3 Maintain Floodplain Functions & 1 & 3 & 7 & 11 & 14 \\
\hline \multirow{2}{*}{$\begin{array}{l}\text { NW3.4 Control Invasive Species } \\
\text { NW3.5 Protect Soil Health }\end{array}$} & 1 & 2 & 6 & 9 & 12 \\
\hline & - & 3 & 4 & 6 & 8 \\
\hline \multicolumn{6}{|l|}{\begin{tabular}{|l|} 
CLIMATE AND RESILIENCE \\
\end{tabular}} \\
\hline \multicolumn{6}{|l|}{ EMISSIONS } \\
\hline \begin{tabular}{|l|} 
CR1.1 Reduce Net Embodied Carbon \\
\end{tabular} & 5 & 10 & 15 & 20 & - \\
\hline CR1.2 Reduce Greenhouse Gas Emissions & 8 & 13 & 18 & 22 & 26 \\
\hline CR1.3 Reduce Air Pollutant Emissions & 2 & 4 & 9 & 14 & 18 \\
\hline \multicolumn{6}{|l|}{ RESILIENCE } \\
\hline \begin{tabular}{|l} 
CR2.1 Avoid Unsuitable Development \\
\end{tabular} & 3 & 6 & 8 & 12 & 16 \\
\hline CR2.2 Assess Climate Change Vulnerability & 8 & 14 & 18 & 20 & - \\
\hline CR2.3 Evaluate Risk \& Resilience & 11 & 18 & 24 & 26 & - \\
\hline CR2.4 Establish Resilience Goals and Strategies & - & 8 & 14 & 20 & - \\
\hline CR2.5 Maximize Resilience & 11 & 15 & 20 & 26 & - \\
\hline CR2.6 Improve Infrastructure Integration & 2 & 5 & 9 & 13 & 18 \\
\hline \begin{tabular}{l|l} 
& Credit applicable \\
\end{tabular} & & & & & \\
\hline Credit not applicable at this phase & & & & & \\
\hline Zero rating & & & & & \\
\hline Credit not applicable & & & & & \\
\hline
\end{tabular}

Figure 5. Scenario 2: Envision evaluation of the project's status. 
A series of suggestions were outlined to be able to raise credit to a higher level and achieve a higher score in the executive project phase. A total of five credits were considered, one for each category.

For the "quality of life" category, the "QL2.2 Encourage Sustainable Transportation" credit was chosen, which responds to the need to expand sustainable transport choices, including shared and mass transport, in order to reduce emissions and improve the air quality. Based on the first assessment, the credit was at the 'enhanced' level. By providing a document which highlights the infrastructure proximity with active, shared and/or mass transport options, explaining the distances, the 'superior' level can be reached.

For the "leadership" category, the "LD1.3 Provide for Stakeholder Involvement" credit was chosen, which analyzes the commitment of the project team in relation to local issues. It enhances the comparison activities between all those involved in the work, promoting shared planning and with attention to the needs of the population. Based on the first assessment, the credit was at the 'superior' level. By providing a document which reports the degree of satisfaction of stakeholders with regard to the decision-making process, the 'conserving' level can be reached.

For the "resource allocation" category, the credit "RA1.2 Use Recycled Materials" was chosen, which enhances the choices of the project team aimed at reducing the use of virgin materials and avoiding the sending of materials still potentially usable to landfill, through their reuse within the project. Based on the first assessment, the credit was at the 'improved' level. By providing a document showing the type of recycled materials and their percentage based on weight or volume or cost, certifying the use of recycled material greater than $25 \%$, the 'superior' level can be reached.

For the "natural world" category, credit "NW2.2 Manage Stormwater" was chosen, which assesses the accumulation capacity of rainwater in the areas affected by the project and the infiltration and evapotranspiration capacity of the area is also assessed. Proper rainwater management reduces the exposure of infrastructures to risks. Based on the first assessment, the credit was at the 'improved' level. By providing a document that studies the area from a hydrogeological point of view, considering the levels of infiltration, evapotranspiration and reuse, it will be possible to access higher levels of performance. Considering the treatment or reuse of $100 \%$ of the 95 th percentile of a daily event with a return time of 50 years, the 'conserving' level can be reached.

For the "climate and resilience" category, the "CR2.6 Improve Infrastructure Integration" credit was chosen, which assesses the degree to which the project is integrated into other connected systems, where advantageous and appropriate, in order to increase the resilience and performance of the system. According to the first assessment, the credit was at level 0 . By providing a document that demonstrates that the project improves the efficiency of the infrastructure asset beyond the boundaries by considering integrated infrastructures, the 'superior level' can be reached.

So, in the second phase two evaluation scenarios have been considered.

The first one (Scenario 3) has been defined assuming the proposed suggestions (Figure 6).

The last one (Scenario 4), instead, was a final evaluation scenario considering a preliminary assessment also for "pending" credits (Figure 7). 


\begin{tabular}{|c|c|c|c|c|c|}
\hline CREDIT & IMPROVED & ENHANCED & SUPERIOR & CONSERVING & RESTORATIVE \\
\hline \multicolumn{6}{|l|}{ QUALITY OF LFE } \\
\hline \multicolumn{6}{|l|}{ WEUBEING } \\
\hline QL1.1 Improve Community Quality of Life & 2 & 5 & 10 & 20 & 26 \\
\hline QL1.2 Enhance Public Health \& Safety & 2 & 7 & 12 & 16 & 20 \\
\hline QL1.3 Improve Construction Safety & 2 & 5 & 10 & 14 & - \\
\hline QL1.4 Minimize Noise \& Vibration & 1 & 3 & 6 & 10 & 12 \\
\hline QL1.5 Minimize Light Pollution & 1 & 3 & 6 & 10 & 12 \\
\hline QL1.6 Minimize Construction Impacts & 1 & 2 & 4 & 8 & - \\
\hline \multicolumn{6}{|l|}{ MOBILTY } \\
\hline QL2.1 Improve Community Mobility \& Access & 1 & 3 & 7 & 11 & 14 \\
\hline QL2.2 Encourage Sustainable Transportation & - & 5 & 8 & 12 & 16 \\
\hline QL2.3 Improve Access \& Wayfinding & 1 & 5 & 9 & 14 & - \\
\hline \multicolumn{6}{|l|}{ COMMUNITY } \\
\hline QL3.1 Advance Equity \& Social Justice & 3 & 6 & 10 & 14 & 18 \\
\hline QL3.2 Preserve Historic \& Cultural Resources & - & 2 & 7 & 12 & 18 \\
\hline QL3.3 Enhance Views \& Local Character & 1 & 3 & 7 & 11 & 14 \\
\hline QL3.4 Enhance Public Space \& Amenities & 1 & 3 & 7 & 11 & 14 \\
\hline \multicolumn{6}{|l|}{ IEADERSHIP } \\
\hline \multicolumn{6}{|l|}{ COLLABORATION } \\
\hline LD1.1 Provide Effective Leadership \& Commitment & 2 & 5 & 12 & 18 & - \\
\hline LD1.2 Foster Collaboration \& Teamwork & 2 & 5 & 12 & 18 & - \\
\hline LD1.3 Provide for Stakeholder Involvement & 3 & 6 & 9 & 14 & 18 \\
\hline LD1.4 Pursue Byproduct Synergies & 3 & 6 & 12 & 14 & 18 \\
\hline \multicolumn{6}{|l|}{ PLANNING } \\
\hline LD2.1 Establish a Sustainability Management Plan & 4 & 7 & 12 & 18 & - \\
\hline LD2.2 Plan for Sustainable Communities & 4 & 6 & 9 & 12 & 16 \\
\hline LD2.3 Plan for Long-Term Monitoring \& Maintenance & 2 & 5 & 8 & 12 & - \\
\hline LD2.4 Plan for End-of-Life & 2 & 5 & 8 & 14 & - \\
\hline \multicolumn{6}{|l|}{ ECONOMY } \\
\hline LD3.1 Stimulate Economic Prosperity \& Development & 3 & 6 & 12 & 20 & - \\
\hline LD3.2 Develop Local Skills \& Capabilities & 2 & 4 & 8 & 12 & 16 \\
\hline LD3.3 Conduct a Life-Cycle Economic Evaluation & 5 & 7 & 10 & 12 & 14 \\
\hline
\end{tabular}

\begin{tabular}{|c|c|c|c|c|c|}
\hline RESOURCE ALLOCATION & & & & & \\
\hline \multicolumn{6}{|l|}{ MATERIALS } \\
\hline RA1.1 Support Sustainable Procurement Practices & 3 & 6 & 9 & 12 & - \\
\hline RA1.2 Use Recycled Materials & 4 & 6 & 9 & 16 & - \\
\hline RA1.3 Reduce Operational Waste & 4 & 7 & 10 & 14 & - \\
\hline RA1.4 Reduce Construction Waste & 4 & 7 & 10 & 16 & - \\
\hline RA1.5 Balance Earthwork On Site & 2 & 4 & 6 & 8 & - \\
\hline \multicolumn{6}{|l|}{ ENERGY } \\
\hline RA2.1 Reduce Operational Energy Consumption & 6 & 12 & 18 & 26 & - \\
\hline RA2.2 Reduce Construction Energy Consumption & 1 & 4 & 8 & 12 & - \\
\hline RA2.3 Use Renewable Energy & 5 & 10 & 15 & 20 & 24 \\
\hline RA2.4 Commission \& Monitor Energy Systems & 3 & 6 & 12 & 14 & - \\
\hline \multicolumn{6}{|l|}{ WATER } \\
\hline RA3.1 Preserve Water Resources & 3 & 5 & 7 & 9 & 12 \\
\hline RA3.2 Reduce Operational Water Consumption & 4 & 9 & 13 & 17 & 22 \\
\hline RA3.3 Reduce Construction Water Consumption & 1 & 3 & 5 & 8 & - \\
\hline RA3.4 Monitor Water Systems & 1 & 3 & 6 & 12 & - \\
\hline
\end{tabular}

\begin{tabular}{|c|c|c|c|c|c|}
\hline \multicolumn{6}{|l|}{ NATURAL WORID } \\
\hline \multicolumn{6}{|l|}{ SITING } \\
\hline NW1.1 Preserve Sites of High Ecological Value & 2 & 6 & 12 & 16 & 22 \\
\hline NW1.2 Provide Wetland \& Surface Water Buffers & 2 & 5 & 10 & 16 & 20 \\
\hline NW1.3 Preserve Prime Farmland & - & 2 & 8 & 12 & 16 \\
\hline NW1.4 Preserve Undeveloped Land & 3 & 8 & 12 & 18 & 24 \\
\hline \multicolumn{6}{|l|}{ CONSERVATION } \\
\hline NW2.1 Reclaim Brownfields & 11 & 13 & 16 & 19 & 22 \\
\hline NW2.2 Manage Stormwater & 2 & 4 & 9 & 17 & 24 \\
\hline NW2.3 Reduce Pesticide \& Fertilizer Impacts & 1 & 2 & 5 & 9 & 12 \\
\hline NW2.4 Protect Surface \& Groundwater Quality & 2 & 5 & 9 & 14 & 20 \\
\hline \multicolumn{6}{|l|}{ ECOLOGY } \\
\hline NW3.1 Enhance Functional Habitats & 2 & 5 & 9 & 15 & 18 \\
\hline NW3.2 Enhance Wetland \& Surface Water Functions & 3 & 7 & 12 & 18 & 20 \\
\hline NW3.3 Maintain Floodplain Functions & 1 & 3 & 7 & 11 & 14 \\
\hline NW3.4 Control Invasive Species & 1 & 2 & 6 & 9 & 12 \\
\hline NW3.5 Protect Soil Health & - & 3 & 4 & 6 & 8 \\
\hline \multicolumn{6}{|l|}{ CLIMATE AND RESILIENCE } \\
\hline \multicolumn{6}{|l|}{ EMISSIONS } \\
\hline CR1.1 Reduce Net Embodied Carbon & 5 & 10 & 15 & 20 & - \\
\hline CR1.2 Reduce Greenhouse Gas Emissions & 8 & 13 & 18 & 22 & 26 \\
\hline CR1.3 Reduce Air Pollutant Emissions & 2 & 4 & 9 & 14 & 18 \\
\hline \multicolumn{6}{|l|}{ RESILIENCE } \\
\hline CR2.1 Avoid Unsuitable Development & 3 & 6 & 8 & 12 & 16 \\
\hline CR2.2 Assess Climate Change Vulnerability & 8 & 14 & 18 & 20 & - \\
\hline CR2.3 Evaluate Risk \& Resilience & 11 & 18 & 24 & 26 & - \\
\hline CR2.4 Establish Resilience Goals and Strategies & - & 8 & 14 & 20 & - \\
\hline CR2.5 Maximize Resilience & 11 & 15 & 20 & 26 & - \\
\hline CR2.6 Improve Infrastructure Integration & 2 & 5 & 9 & 13 & 18 \\
\hline
\end{tabular}

\begin{tabular}{|l|l|}
\hline & Credit applicable \\
\hline & Credit not applicable at this phase \\
\hline & Zero rating \\
\hline & Credit not applicable \\
\hline
\end{tabular}

Figure 6. Scenario 3: Envision evaluation of the project assuming the proposed suggestions. 


\begin{tabular}{|c|c|c|c|c|c|}
\hline CREDIT & IIMPROVED & ENHANCED & SUPERIOR & CONSERVING & RESTORATIVE \\
\hline \multicolumn{6}{|l|}{ QUALITY OF LIFE } \\
\hline \multicolumn{6}{|l|}{ WELLBEING } \\
\hline QL1.1 Improve Community Quality of Life & 2 & 5 & 10 & 20 & 26 \\
\hline QL1.2 Enhance Public Health \& Safety & 2 & 7 & 12 & 16 & 20 \\
\hline QL1.3 Improve Construction Safety & 2 & 5 & 10 & 14 & - \\
\hline QL1.4 Minimize Noise \& Vibration & 1 & 3 & 6 & 10 & 12 \\
\hline QL1.5 Minimize Light Pollution & 1 & 3 & 6 & 10 & 12 \\
\hline QL1.6 Minimize Construction Impacts & 1 & 2 & 4 & 8 & - \\
\hline \multicolumn{6}{|l|}{ MOBILTY } \\
\hline QL2.1 Improve Community Mobility \& Access & 1 & 3 & 7 & 11 & 14 \\
\hline QL2.2 Encourage Sustainable Transportation & - & 5 & 8 & 12 & 16 \\
\hline QL2.3 Improve Access \& Wayfinding & 1 & 5 & 9 & 14 & - \\
\hline \multicolumn{6}{|l|}{\begin{tabular}{|l} 
COMMUNITY \\
\end{tabular}} \\
\hline QL3.1 Advance Equity \& Social Justice & 3 & 6 & 10 & 14 & 18 \\
\hline QL3.2 Preserve Historic \& Cultural Resources & - & 2 & 7 & 12 & 18 \\
\hline QL3.3 Enhance Views \& Local Character & 1 & 3 & 7 & 11 & 14 \\
\hline QL3.4 Enhance Public Space \& Amenities & 1 & 3 & 7 & 11 & 14 \\
\hline \multicolumn{6}{|l|}{ LEADERSHIP } \\
\hline \multicolumn{6}{|l|}{ COLLABORATION } \\
\hline LD1.1 Provide Effective Leadership \& Commitment & 2 & 5 & 12 & 18 & - \\
\hline LD1.2 Foster Collaboration \& Teamwork & 2 & 5 & 12 & 18 & - \\
\hline LD1.3 Provide for Stakeholder Involvement & 3 & 6 & 9 & 14 & 18 \\
\hline LD1.4 Pursue Byproduct Synergies & 3 & 6 & 12 & 14 & 18 \\
\hline \multicolumn{6}{|l|}{ PLANNING } \\
\hline LD2.1 Establish a Sustainability Management Plan & 4 & 7 & 12 & 18 & - \\
\hline LD2.2 Plan for Sustainable Communities & 4 & 6 & 9 & 12 & 16 \\
\hline LD2.3 Plan for Long-Term Monitoring \& Maintenance & 2 & 5 & 8 & 12 & - \\
\hline LD2.4 Plan for End-of-Life & 2 & 5 & 8 & 14 & - \\
\hline \multicolumn{6}{|l|}{\begin{tabular}{|l} 
ECONOMY \\
\end{tabular}} \\
\hline LD3.1 Stimulate Economic Prosperity \& Development & 3 & 6 & 12 & 20 & - \\
\hline LD3.2 Develop Local Skills \& Capabilities & 2 & 4 & 8 & 12 & 16 \\
\hline LD3.3 Conduct a Life-Cycle Economic Evaluation & 5 & 7 & 10 & 12 & 14 \\
\hline
\end{tabular}

\begin{tabular}{|c|c|c|c|c|c|}
\hline \multicolumn{6}{|l|}{ RESOURCE ALLOCATION } \\
\hline MATERIALS & & & & & \\
\hline RA1.1 Support Sustainable Procurement Practices & 3 & 6 & 9 & 12 & - \\
\hline RA1.2 Use Recycled Materials & 4 & 6 & 9 & 16 & - \\
\hline RA1.3 Reduce Operational Waste & 4 & 7 & 10 & 14 & - \\
\hline RA1.4 Reduce Construction Waste & 4 & 7 & 10 & 16 & - \\
\hline RA1.5 Balance Earthwork On Site & 2 & 4 & 6 & 8 & - \\
\hline \multicolumn{6}{|l|}{ ENERGY } \\
\hline RA2.1 Reduce Operational Energy Consumption & 6 & 12 & 18 & 26 & - \\
\hline RA2.2 Reduce Construction Energy Consumption & 1 & 4 & 8 & 12 & - \\
\hline RA2.3 Use Renewable Energy & 5 & 10 & 15 & 20 & 24 \\
\hline RA2.4 Commission \& Monitor Energy Systems & 3 & 6 & 12 & 14 & - \\
\hline \multicolumn{6}{|l|}{ WATER } \\
\hline RA3.1 Preserve Water Resources & 3 & 5 & 7 & 9 & 12 \\
\hline RA3.2 Reduce Operational Water Consumption & 4 & 9 & 13 & 17 & 22 \\
\hline RA3.3 Reduce Construction Water Consumption & 1 & 3 & 5 & 8 & - \\
\hline RA3.4 Monitor Water Systems & 1 & 3 & 6 & 12 & - \\
\hline
\end{tabular}

\begin{tabular}{|c|c|c|c|c|c|}
\hline \multirow{2}{*}{\multicolumn{6}{|c|}{\begin{tabular}{|l|} 
NATURAL WORLD \\
SITING \\
\end{tabular}}} \\
\hline & & & & & \\
\hline NW1.1 Preserve Sites of High Ecological Value & 2 & 6 & 12 & 16 & 22 \\
\hline NW1.2 Provide Wetland \& Surface Water Buffers & 2 & 5 & 10 & 16 & 20 \\
\hline NW1.3 Preserve Prime Farmland & - & 2 & 8 & 12 & 16 \\
\hline NW1.4 Preserve Undeveloped Land & 3 & 8 & 12 & 18 & 24 \\
\hline \multicolumn{6}{|l|}{ CONSERVATION } \\
\hline NW2.1 Reclaim Brownfields & $\overline{11}$ & 13 & 16 & 19 & 22 \\
\hline NW2.2 Manage Stormwater & 2 & 4 & 9 & 17 & 24 \\
\hline NW2.3 Reduce Pesticide \& Fertilizer Impacts & 1 & 2 & 5 & 9 & 12 \\
\hline NW2.4 Protect Surface \& Groundwater Quality & 2 & 5 & 9 & 14 & 20 \\
\hline \multicolumn{6}{|l|}{ ECOLOGY } \\
\hline NW3.1 Enhance Functional Habitats & 2 & 5 & 9 & 15 & 18 \\
\hline NW3.2 Enhance Wetland \& Surface Water Functions & 3 & 7 & 12 & 18 & 20 \\
\hline NW3.3 Maintain Floodplain Functions & 1 & 3 & 7 & 11 & 14 \\
\hline NW3.4 Control Invasive Species & 1 & 2 & 6 & 9 & 12 \\
\hline NW3.5 Protect Soil Health & - & 3 & 4 & 6 & 8 \\
\hline \multicolumn{6}{|l|}{ CUIMATE AND RESILIENCE } \\
\hline \multicolumn{6}{|l|}{ EMISSIONS } \\
\hline CR1.1 Reduce Net Embodied Carbon & 5 & 10 & 15 & 20 & - \\
\hline CR1.2 Reduce Greenhouse Gas Emissions & 8 & 13 & 18 & 22 & 26 \\
\hline CR1.3 Reduce Air Pollutant Emissions & 2 & 4 & 9 & 14 & 18 \\
\hline \multicolumn{6}{|l|}{ RESILIENCE } \\
\hline CR2.1 Avoid Unsuitable Development & 3 & 6 & 8 & 12 & 16 \\
\hline CR2.2 Assess Climate Change Vulnerability & 8 & 14 & 18 & 20 & - \\
\hline CR2.3 Evaluate Risk \& Resilience & 11 & 18 & 24 & 26 & - \\
\hline CR2.4 Establish Resilience Goals and Strategies & - & 8 & 14 & 20 & - \\
\hline CR2.5 Maximize Resilience & 11 & 15 & 20 & 26 & - \\
\hline CR2.6 Improve Infrastructure Integration & 2 & 5 & 9 & 13 & 18 \\
\hline
\end{tabular}

\begin{tabular}{|l|l|}
\hline & Credit applicable \\
\hline & Credit not applicable at this phase \\
\hline & Zero rating \\
\hline & Credit not applicable \\
\hline
\end{tabular}

Figure 7. Scenario 4: Envision evaluation of the project assuming the proposed suggestions and considering the pending credits. 


\section{Obtained Results}

The first scenario (Scenario 1) allowed us to understand which credits can be evaluated with the available project documentation without going into the merits of the performance level obtained for the single credit. The percentage ratio achieved is less representative of a project evaluation. With the documentation available, it is possible to assess 51 of the 64 total credits of the framework, corresponding to about $80 \%$ of the credits.

The second scenario (Scenario 2) represents a snapshot of the state of the project, attributing a performance level to the credits for which it was possible to make an assessment. In this case, the percentage ratio reached exceeds the validation threshold, reaching a 'Verified' certification level. It should be noted that the rating of the project took place by treating the "pending" credits (credits whose evaluation can be confirmed only after the construction of the work) similarly to credits "not applicable".

The third scenario (Scenario 3) considers the effect of the improvement in the performance level obtained by analyzing the potential increases. For the five credits previously identified, one for each category into which the framework is divided, it was assumed that a higher level of performance had been achieved than the previous evaluation. In this case, the percentage ratio obtained stands at a rating level equal to Silver.

In the fourth and last scenario (Scenario 4), a preliminary assessment also for 'pending' credits have been evaluated. By entering the evaluation of these credits, the rating at the 'Silver' level is confirmed.

It has been seen that the highest scores were totaled in the 'quality of life' and 'natural world' categories (credits QL1.1, QL1.4, QL2.1, NW1.1, N.W1.2, N.W1. 3).

In particular, in the 'quality of life' category, specific studies relating to the needs, objectives, and problems of the community and stakeholder participation in the decisionmaking process determined the attribution of the score. Extensive research about the evaluation of noise and vibrations will be expected during operation and of strategies to mitigate and reduce them, contributing to the score. In addition, the credits related to the accessibility and mobility of the community and, above all, the ways in which the infrastructure helps to improve them were also influential. Improving the practicality and mobility of the community is the main reason for the up-grading project, which aims to reduce congestion and decrease travel times.

For the 'natural world' category, the enhancement or new construction of cycle paths, the landscape protection of critical areas, the creation of green areas, and specific tree bands were decisive, since these actions aimed at perfecting the environmental integration of the work.

The factor that would make it possible to obtain a high level of credits (up to the highest level of certification) is the analysis of the risks associated with the work (CR2.3 credit). The risks include all those that the infrastructure could face during its operation (e.g., seismic events, hurricanes, floods), including those connected to integrated works.

Studies relating to the 'climate' and 'resilience' category are those that have most affected the attribution of the current score. If they are increased in the next phase of the design, they will allow one to reach the highest levels of Envision certification.

\section{Conclusions}

The obtained results have highlighted that the Envision framework is a very useful support for the evaluation of the sustainability of a road project. Using it from the preliminary studies to the end of construction, it allows one to determine the level of sustainability of the upgrading work project and to raise its level of verification by means of appropriate documentation in the subsequent design phases, reaching of the highest levels of certification. For the project object of study, the highest scores were totaled in the 'quality of life' and 'natural world' categories.

In the first one the strategies to mitigate and reduce noise and vibrations represent the more important contribute to the score. In addition, the credits related to the accessibility 
and mobility of the community and, above all, the ways in which the infrastructure helps to improve them were also influential.

For the 'natural world' category, the enhancement or new construction of cycle paths, the landscape protection of critical areas, the creation of green areas, and specific tree bands were decisive.

The factor that would make it possible to obtain a high level of credits (up to the highest level of certification) is the analysis of the risks associated with the work, including those connected to integrated works.

The results obtained allow to outline the current level of the work that is verified for the framework evaluation criteria (Verified) and highlighted the percentage increase in evaluation until the next performance level (Silver) that is reached in the last two scenarios.

The future of infrastructure design is sustainability. Until recently, it was believed that sustainability represented a cost and a brake on growth. Now it is believed that being sustainable is an added value. Sustainability therefore becomes necessary for the development of communities. Creating a sustainable world is therefore possible, so long as we have adequate guidelines. Tools such as the developed framework are essential to meet the needs of future generations in the context of infrastructure design.

Author Contributions: Conceptualization, A.B.; Methodology, A.B. and F.C.; Data Curation, F.C.; Writing-Original Draft Preparation, F.C. and L.C.; Writing-Review and Editing, L.C. and V.V.; Supervision, V.V. All authors have read and agreed to the published version of the manuscript.

Funding: This research received no external funding.

Institutional Review Board Statement: Not applicable.

Informed Consent Statement: Not applicable.

Data Availability Statement: Data sharing is not applicable to this article.

Conflicts of Interest: The authors declare no conflict of interest.

\section{References}

1. Sustainable Development Agenda. Available online: https://www.un.org/sustainabledevelopment/development-agenda/ (accessed on 20 December 2021).

2. Hutchins, M.J.; Sutherland, J.W. An exploration of measures of social sustainability and their application to supply chain decisions. J. Clean. Prod. 2008, 16, 1688-1698. [CrossRef]

3. Willetts, R.; Burdon, J.; Glass, J.; Frost, M. Environmental and sustainability impact assessment of infrastructure in the United Kingdom. Transp. Res. Record. 2010, 2158, 143-150. [CrossRef]

4. Kumar, A.S. Environmental indicators for sustainable road development and operation. In Proceedings of the International Journal of Pavements Conference 2013, São Paulo, Brazil, 9-10 December 2013.

5. Improving Environmental Sustainability in Road Projects. Available online: https://openknowledge.worldbank.org/handle/10 986/21563 (accessed on 20 December 2021).

6. Marzouk, M.M.; El Zayat, M.; Aboushady, A. Assessing environmental impact indicators in road construction projects in developing countries. Sustainability 2017, 9, 843. [CrossRef]

7. Griffiths, K.; Boyle, C.; Henning, T.F.P. Sustainability rating tools for highway projects: The nature and outcomes of use. Infrast. Asset Manag. 2018, 5, 2. [CrossRef]

8. Hojjati, A.; Jefferson, I.; Metje, N.; Rogers, C.D.F. Sustainability assessment for urban underground utility infrastructure projects. Proc. Inst. Civil Eng. 2018, 171, 68-80. [CrossRef]

9. Shafiq, A.; Arun, K.; Dawes, L. Sustainability assessment of road infrastructure using sustainability index. Infrast. Asset Manag. 2018, 5, 3-13.

10. Krajangsri, T.; Pongpeng, J. Sustainable Infrastructure Assessment Model: An application to road projects. KSCE J. Civil Eng. 2019, 23, 973-984. [CrossRef]

11. Suprayoga, B.G.; Bakker, M.; Witte, P.; Spit, T. A systematic review of indicators to assess the sustainability of road infrastructure projects. Eur. Trans. Res. Rev. 2020, 12, 1. [CrossRef]

12. Dondi, G.; Sangiorgi, C.; Lantieri, C.; Simone, A.; Vignali, V.; Lamperti, R. Performance evaluation of Construction and Demolition and other waste materials. In Proceedings of the 3rd International Conference on Transportation Infrastructures-ICTI 2014, Pisa, Italy, 22-25 April 2014; pp. 1-11.

13. Tataranni, P.; Sangiorgi, C.; Simone, A.; Vignali, V.; Lantieri, C.; Dondi, G. A laboratory and field study on $100 \%$ Recycled Cement Bound Mixture for base layers. Int. J. Pavement Res. Tech. 2017, 10, 45-53. [CrossRef] 
14. Celauro, B.; Celauro, C.; Lo Presti, D.; Bevilacqua, A. Definition of a laboratory optimization protocol for road bitumen improved with recycled tire rubber. Constr. Build. Mater. 2012, 37, 562-572. [CrossRef]

15. Pettinari, M.; Simone, A. Effect of crumb rubber gradation on a rubberized cold recycled mixture for road pavements. Mater. Des. 2015, 85, 598-606. [CrossRef]

16. Vignali, V.; Mazzotta, F.; Sangiorgi, C.; Simone, A.; Lantieri, C.; Dondi, G. Incorporation of rubber powder as filler in a new dry-hybrid technology: Rheological and 3D DEM mastic performances evaluation. Materials 2016, 9, 842. [CrossRef] [PubMed]

17. Sangiorgi, C.; Tataranni, P.; Simone, A.; Vignali, V.; Lantieri, C.; Dondi, G. Stone Mastic Asphalt (SMA) with crumb rubber according to a new dry-hybrid technology: A laboratory and trial field evaluation. Constr. Build. Mater. 2018, 182, 200-209. [CrossRef]

18. Bressi, S.; Fiorentini, N.; Huang, J.; Losa, M. Crumb rubber modifier in road asphalt pavements: State of the art and statistics. Coatings 2019, 9, 384. [CrossRef]

19. Bressi, S.; Santos, J.; Orešković, M.; Losa, M. A comparative environmental impact analysis of asphalt mixtures containing crumb rubber and reclaimed asphalt pavement using life cycle assessment. Int. J. Pavem. Eng. 2021, 22, 524-538. [CrossRef]

20. Subhy, A.; Lo Presti, D.; Airey, G.; Widyatmoko, I. Rutting analysis of different rubberized stone mastic asphalt mixtures: From binders to mixtures. Road Mater. Pavem. Des. 2021, 1, 1-17.

21. Sangiorgi, C.; Tataranni, P.; Mazzotta, F.; Simone, A.; Vignali, V.; Lantieri, C. Alternative fillers for the production of bituminous mixtures: A screening investigation on waste powders. Coatings 2017, 7, 76. [CrossRef]

22. Mazzotta, F.; Sangiorgi, C.; Vignali, V.; Lantieri, C.; Dondi, G. Rheological characterization of bituminous mastics added with waste bleaching clays. In Proceedings of the 8th RILEM International Symposium on Testing and Characterization of Sustainable and Innovative Bituminous Materials, Ancona, Italy, 7-9 October 2015.

23. Simone, A.; Mazzotta, F.; Eskandarsefat, S.; Sangiorgi, C.; Vignali, V.; Lantieri, C.; Dondi, G. Experimental application of waste glass powder filler in recycled dense-graded asphalt mixtures. Road Mater. Pavem. Des. 2019, 20, 592-607. [CrossRef]

24. Bassani, M.; Tefa, L.; Russo, A.; Palmero, P. Alkali-activation of recycled construction and demolition waste aggregate with no added binder. Constr. Build. Mater. 2019, 205, 398-413. [CrossRef]

25. Veropalumbo, R.; Viscione, N.; Formisano, A. Hot mix asphalt with fly ashes for dense-graded surface layers of rural roads. WIT Trans. Ecol. Environ. 2018, 215, 93-105.

26. Oreto, C.; Russo, F.; Veropalumbo, R.; Biancardo, S.A.; Dell'acqua, G. Life cycle assessment of sustainable asphalt pavement solutions involving recycled aggregates and polymers. Materials 2021, 14, 3867. [CrossRef] [PubMed]

27. Capuano, L.; Magatti, G.; Perucca Dettori, M.; Mantecca, P. Use of recycled plastics as a second raw material in the production of road pavements: An example of circular economy evaluated with LCA methodology. Procedia Environ. Sci. Eng. Manag. 2020, 7, $37-43$.

28. Celauro, C.; Teresi, R.; Graziano, F.; Mantia, F.P.L.; Protopapa, A. Preliminary evaluation of plasmix compound from plastics packaging waste for reuse in bituminous pavements. Sustainability 2021, 13, 2258. [CrossRef]

29. Giunta, M.; Mistretta, M.; Praticò, F.G.; Gulotta, M.T. Environmental sustainability and energy assessment of bituminous pavements made with unconventional materials. Lect. Notes Civil Eng. 2020, 48, 123-132.

30. Veropalumbo, R.; Russo, F.; Oreto, C.; Zhang, W.; Viscione, N. Verifying laboratory measurement of the performance of hot asphalt mastics containing plastic waste. Measurement 2021, 180, 109587. [CrossRef]

31. Umer, A.; Hewage, K.; Haider, H.; Sadiq, R. Sustainability assessment of roadway projects under uncertainty using Green Proforma: An index-based approach. Int. J. Sustain. Built Environ. 2016, 5, 604-619. [CrossRef]

32. Singh, R.K.; Murty, H.R.; Gupta, S.K.; Dikshit, A.K. An overview of sustainability assessment methodologies. Ecol. Indic. 2012, 15, 281-299. [CrossRef]

33. Muench, S.T. Roadway construction sustainability impacts: Review of life-cycle assessments. Transp. Res. Rec. 2010, 2151, 36-45. [CrossRef]

34. Bueno, P.C.; Vassallo, J.M.; Cheung, K. Sustainability assessment of transport infrastructure projects: A review of existing tools and methods. Transp. Rev. 2015, 35, 5. [CrossRef]

35. Lee, J.; Edil, T.B.; Benson, C.H.; Timjum, J.M. Building environmentally and economically sustainable transportation infrastructure: Green highway rating system. J. Constr. Eng. Manag. 2013, 139, A4013006. [CrossRef]

36. Institute for Sustainable Infrastructure. Envision: Sustainable Infrastructure Framework Guidance Manual, 3rd ed.; Institute for Sustainable Infrastructure: Washington, DC, USA, 2018.

37. Mattinzioli, T.; Sol-Sánchez, M.; Martínez, G.; Rubio-Gámez, M. A critical review of roadway sustainable rating systems. Sustain. Cities Soc. 2020, 63, 102447. [CrossRef]

38. Szpotowicz, R.; Toth, C. Revision of Sustainable Road Rating Systems: Selection of the Best Suited System for Hungarian Road Construction Using TOPSIS Method. Sustainability 2020, 12, 8884. [CrossRef]

39. Scisciot, F. The Development for the Bologna Ring Road and Motorway System: The Experience of Public Discussion. 2017. Available online: https: / www.flowsmag.com/2017/09/20/the-development-project-for-the-bologna-ring-road-and-motorwaysystem/ (accessed on 19 December 2021). 